\title{
KEMENANGAN MENAHAN HAWA NAFSU \\ Sebuah Perbandingan Hari Raya Idul Fitri dan Hari Raya Galungan
}

\author{
Putri Maharani \\ Fakultas Ushuluddin UIN Suska Riau \\ Email: Putrimaharani.pm45@gmail.com
}

\begin{abstract}
Abstrak
Tulisan ini mengkaji tentang tata cara pelaksanaan Hari Raya Idul Fitri dalam Islam dan Hari Raya Galungan dalam Hindu.Terdapat persamaan dan perbedaan antara kedua hari raya tersebut, karena ada beberapa persamaan makna yaitu memiliki arti kemenangan diantara kedua hari raya tersebut. Disinilah penulis tertarik untuk melakukan penelitian dengan judul tersebut. Penelitian ini merupakan penelitian kepustakaan (Library Reseach), yang merujuk pada buku-buku yang memang khusus membahas permasalahan ini sebagai data primer, sementara data sekunder diambil dari buku-buku yang ditulis oleh orang-orang yang memang ahli tentang Hari Raya Idul Fitri dan Hari Raya Galungan seperti ensiklopedia, artikel dan skripsi. Dalam menganalisis data yang diperoleh dan diolah penulis menggunakan Content analiysis, yakin metode untuk mengetahui prinsip-prinsip dari suatu konsep untuk keperluan mendeskripsikan secara objekti-sistemasis tentang suatu teks. Hasil temuan dari permasalahan tersebut didapatkan bahwa persamaan mendasar dari kedua agama tersebut di hal makna hari raya Idul Fitri merupakan suatu kemenangan karena telah melakukan ibadah yaitu berpuasa. Kemenangan melawan hawa nafsu, setelah sebulan berpuasa manusia dapat dorongan dari dalam diri seseorang, oleh karena itu melawan hawa nafsu harus mampu dikendalikan oleh diri sendiri. Han hari raya galungan merupakan suatu kemenangan antara Dharma (kebaikan) dan Adharma (keburukan). Perbedaan mendasar dari keduanya adalah sejarah adanya hari raya tersebut, serta tata cara pelaksaannya sendiri
\end{abstract}

Kata Kunci: Hari Raya, Idhul Fitri, Galungan

Pendahuluan

Terdapat banyak perayaan agama yang bermakna sama dari agama yang berbeda. Mencari persamaan dalam kehidupan berbangsa yang beraneka ragam suku, agama dan ras sangat perlu demikian juga perlu mencari perbedaan untuk menemukan persamaan. Dari beberapa persamaan makna suatu perayaan keagamaan adalah Idul Fitri dan Galungan.

Didalam Islam terdapat 2 hari raya yaitu hari raya Idul Fitri dan hari raya Idul Adha. Idul Fitri memiliki nilai sosial yaitu berkumpulnya sanak saudara sambil 
bersilaturahmi terhadap lingkungan sekitar, serta memiliki nilai ekonomis, yaitu membeli baju baru, dan perlengkapan untuk menyambut dan memeriahkan hari raya ini.

Perayaan hari raya Idul Fitri yang menjadi tradisi umat Islam dilaksanakan dalam kurun waktu setahun sekali setelah melaksanakan puasa Ramadhan. Akan tetapi untuk menempuh perayaan tersebut, umat Islam terlebih dahulu menjalankan ibadah puasa yang ditetapkan rukun dan syarat yang telah ditetapkan dengan penuh keikhlasan maka ia telah terbebas dari tanggungannya serta tidak ada orang lain yang mempunyai alasan untuk menghukumnya (Ihyaul Ulumuddin: 2010).

Idul Fitri adalah hari pertama setelah berakhirnya Ramadhan. Hari kemenangan, karena berhasil menaklukan hawa nafsu; hari kembali suci, karena membersihkan diri dan Allah mengampuni dosa-dosa muslim yang berpuasa (Jejen musfah, 2016).

Ada sebuah riwayat yang menceritakan tentang asal mula terjadinya Hari Raya Idul Fitri disyari'atkan pada tahun pertama bulan Hijriyah, namun hari dilaksanakan pada tahun kedua Hijriyah. Pada masa Rasulullah SAW, di sebuah kota yang terletak di Madinah ada dua hari yang didalamnya terdapat kaum-kaum Yasyrik yang menggunakan dua hari tersebut dengan berpesta-pesta dan bersenangsenang semata, yang terkesan lebih berfoya-foya. Kedua hari tersebut dinamakan hari An-Nairuz dan hari AlMuhrajan (Bahannan, 2002:214).

Ketika hal tersebut menjadisebuah tradisi dan budaya kaum Yatsrib, sampailah kabar tersebut pada Rasullah SAW. Sehingga Rasullah ingin mencari tahu, bahwa apa yang sedang mereka lakukan dengan kedua hari tersebut. Kemudian orang-orang Madinah pun menjawab : "Wahai Rasul pada hari ini kami sedang merayakan pesta untuk kesenangan dan kepuasan kita dan kita akan menjadikan hari ini menjadi sebuah tradisi kita karena hari ini sudah ada sejak zaman kaum Jahiliyah" (Bahannan, 2002:214).

Mendengar hal tersebut Rasulullah kaget dan tersentak hatinya untuk menyuruh mereka berhenti melakukan hal yang tidak bermanfaat. Sehingga kemudian Rasulullah berkata kepada kaum Yatsrib tersebut, kalian harus tahu bahwa sesungguhnya Allah menggantikan kedua hari tersebut dengan hari yang lebih baik dari pada sekedar berpesta-pesta dan berfoya-foya saja yang hanya akan menjadikan kalian umat yang bodoh yang akan menggunakan waktu dan harta kalian dengan Mubazir atau sia-sia. Sungguh Allah 
SW'T telah menggantikan kedua hari tersebut dengan Hari Raya Idul Fitri dan Hari Raya Idul Adha, yang penuh dengan makna dan hikmah-hikmahnya.

Pristiwa tersebut menjadi sebuah riwayat Hadist yang terdapat di buku AlJaziri (Tth:271):

"Ketika Nabi shallallahu 'alaibi wa sallam datang ke Madinah, penduduk. Madinab memiliki dua hari raya untuk bersenang-senang dan bermain-main di masa jabiliyah. Maka beliau berkata, "Aku datang kepada kealian dan kalian mempunyai dua hari raya di masa Jabiliyah yang kalian isi dengan bermainmain. Allab telah mengganti keduanya dengan yang lebih baik bagi kalian, yaitu hari raya Idul Fithri dan Idul Adha (hari Nabr)" (HR. An Nasai no. 1556 dan Abmad 3: 178, sanadnya shabih sesuai syarat Bukhari-Muslim sebagaimana kata Syaikh Syu'aib Al Arnauth".

Jadi, sejarah Idul Fitri tersebut merupakan perubahan dari yang tidak memiliki manfaat yang baik sampai akhirnya menjadi bagian ibadah dari umat Islam yang memiliki keberkahan.

Sementara itu, dalam tradisi agama Hindu, ada perayaan galungan. Galungan adalah pemujaan kepada Hyang Widhi yang dilakukan dengan penuh kesucian dan ketulusan hati, memohon kesejahteraan dan keselamatan hidup serta agar dijauhkan dari awidya. Galungan adalah hari pawedalam jagat, yaitu pemujaan bahwa telah terciptanya jagat dengan segala isinya oleh Hyang Widhi. Hari ini dirayakan masih sulit ditentukan, hanya menurut keterangan hari raya tersebut dilaksanakan pada tahun saka 804 (Khotimah, 2013:140).

Galungan merupakan lambang perjuangan antara yang benar (Dharma) melawan yang tidak benar (Adharma) dan juga sebagai pernyataan rasa terimakasih atas kemakmuran dalam alam yang diciptakan Hyang Widhi (Khotimah, 2013:140). Dengan kemenangan Dharma juga memiliki makna berarti telah terlaksanakannya kewajiban dan pekerjaanpekerjaan yang baik, yang sangat bermanfaat untuk dirinya sendiri, keluarganya, dan untuk semua umat manusia. Bagi umat Hindu itu sendiri pekerjaan-pekerjaan yang baik merupakan Yajna, oleh karena itu dalam perayaan hari raya Galungan maka persembahan Yajna merupakan tujuan yang paling utama telah dilakukan umat manusia (Krisnawati, 2019:36).

Perayaan keagamaan memang selalu menjadi moment yang sangat di nanti-nanti oleh umat di masing-masing agama tersebut,. Perayaan keagamaan tersebut di sambut sangat antusias oleh seluruh manusia, tidak terkecuali Indonesia. Di Indonesia terdapat 6 agama yaitu Islam, Hindu, Budha, Kristen, Katholik dan Konghucu, yang setiap agamanya memiliki hari perayaan 
keagamaan tersendiri, contohnya Idul Fitri dalam Islam dan Galungan dalam Hindu.

Nuansa penyambutan hari raya besar umat Islam yakni Idul Fitri sangat terasa di Indonesia, dimana pada hari raya ini semua keluarga besar berkumpul dan menjalin silaturahmi kembali, tradisi balik kampung atau mudik sering sekali menjadi kebiasaan keluarga yang jauh kembali kekampung halaman. Fenomena mudik ini memiliki cerita tersendiri. Tidak hanya mudik, ada satu lagi Fenomena dihari raya ini yaitu membagi-bagikan THR atau Tunjangan Hari Raya, yaitu amplop-amplop yang berisikan uang lalu dibagikan kepada saudara-saudara lainnya.

Hari raya Idul Fitri juga membuat peningkatan ekonomi khususnya di masyarakat yang berjualan dipasar. Fenomena yang terjadi yaitu, membeli baju baru adalah salah satu kebiasaan untuk menyambut Idul Fitri atau yang sering sekali disebut dengan lebaran, tidak hanya membeli baju, dipasar juga banyak menjual kue-kue kering, ketupat dan hal lainnya yang bisa dijadikan makanan untuk tamu yang datang bersilaturahmi pada hari itu.

Hari raya Galungan dirayakan oleh umat Hindu Bali setiap 210 hari, dengan menggunakan perhitungan kalender Bali yaitu pada hari Budha Kliwon Dungulan (Rabu Kliwon wuku Dungulan) sebagai hari kemenangan Dharma (kebenaran) melawan Adharma (kejahatan).

Hari raya Galungan juga dirayakan oleh masyarakat Tengger dengan makna dan cara yang berbeda dengan masyarakat Bali, setidaknya hingga introduksi agama Hindu Dharma ke kawasan Tengger tahun 1980an Masyarakat Tengger merayakan Galungan setiap 210 hari sekali di wuku galungan sebagai hari untuk memberkati desa, air, dan masyarakat. Tatacara perayaannya identik dengan Barikan, satu upacara lain yang biasanya dilakukan tiap 35 hari sekali atau setelah bencana seperti gunung meletus, gempa, atau gerhana. Berbeda dengan Barikan, hari raya Galungan Tengger sudah tidak dilaksanakan dengan cara Tengger namun telah disatukan dengan perayaan galungan sesuai tatacara Hindu Bali.Makna hari raya Galungan bagi masyarakat Tengger adalah menghaturkan rasa terimakasih kepada Sang Hyang Widhi atas terciptanya dunia dan segala isinya, dan sabagai rasa syukur atas segala karunianya. Sedangkan menurut masyarakat Bali makna dari hari raya Galungan ini adalah upacara kegamaan yang paling penting, mereka mempercayaai bahwa roh para leluhur akan pulang kerumah dan mereka wajib menyambut dengan membacakan doa dan persembahan. Tetapi keduanya tetap 
menjadikan hari raya Galungan sebagai makna dari kemenangan Dharma melawan Adharma.

Sama halnya dengan Galungan yaitu hari raya keagamaan umat Hindu yang dilakukan secara rutin setiap Budha Kliwon Dungulan. Terdapat banyak perayaan agama yang bermakna sama dari agama yang berbeda. Mencari persamaan dalam kehidupan berbangsa yang beraneka ragam suku, agama dan ras sangat perlu demikian juga perlu mencari perbedaan untuk menemukan persamaan.Dari beberapa persamaan makna suatu perayaan keagamaan salah satunya adalah Idul fitri dan Galungan. Hari raya idul fithri merupakan puncak dari seluruh rangkaian proses ibadah selama bulan Ramadhan. Idul Fitri disebut-sebut sebagai 'Hari Kemenangan' , menurut Zainul Alim (2012) hari raya Idul Fitri dan kemerdekaan Indonesia mempunyai falsafah yang sama yaitu simbol kemerdekaan dan hari kemenangan. Mengapa Idul Fitri disebutsebut sebagai 'Hari Kemenangan' ? Pertama, dari kata idul fithri itu sendiri yang berarti kembali ke fitrah, yakni 'asal kejadian', atau 'kesucian', atau 'agama yang benar'. Maka setiap orang yang merayakan idul fitri dianggap sebagai cara seseorang untuk kembali kepada ajaran yang benar, sehingga dia bisa memperoleh kemenangan. Kedua, dari kata 'minal 'aidin wal faizin' yang berarti 'semoga kita termasuk orang-orang yang kembali memperoleh kemenangan'. Karena kata minal aidin wal faizin adalah ucapan yang lumrah diucapkan.Menurut para ahli, kata al-faizin diambil dari kata fawz, sebagaimana tersebut dalam Al-Qur'an, yang berarti 'keburuntungan' atau 'kemenangan'. Makna yang sama sebagai hari kemenangan bagi umat Hindu adalah hari raya Galungan, hari raya galungan jatuh pada hari Rabu Kliwon wuku Dungulan.

Dari penjelasan latar belakang diatas, alasan penulis mengambil judul ini adalah,karena hari raya Idul Fitri (Agama Islam) dan hari raya Galungan (Agama Hindu) terdapat beberapa perbedaan dan persamaan di dalamnya. Dan judul ini termasuk kedalam lintas agama (agama samawi dan agama ardi), sehingga dinilai perlu untuk menjadi bahan referensi penulisan karya ilmiah prodi Studi AgamaAgama kedepannya.

Berdasarkan latar belakang masalah yang telah dikemukakan, kiranya dapat dijadikan penelitian yang terarah dan lebih terfokus, maka permasalahan yang akan dibahas dalam penelitian ini dapat dirumuskan yaitu sebagai berikut: apa makna dari Idul Fitri dalam Islam dan 
Galungan dalam Hindu? Dan apakah persamaan dan perbedaan Idul Fitri dan Galungan?

\section{Kerangka Teori}

Pada dasarnya Hari raya adalah semua hari yang didalamnya terdapat sekumpulan orang yang merayakannya, khususnya untuk agama-agama yang mempunyai perayaan-perayaan hari raya besar ataupun kecil. Disetiap agama memilki hari raya atau hari-hari besarnya tersendiri, yaitu Islam dengan Idul Fitri, idul adha dan lainnya, Kristen yang memiliki hari Natal, Hindu yang memiliki hari raya kuningan, galungan dan lainnya.

Di dalam berbagai agama tersebut, memiliki makna hari rayanya masingmasing, yaitu : menurut Agama Islam, tanggal satu Syawal merupakan hari besar umat Islam setelah mereka beribadah piasa selama satu bulan lamanya. Pada hari itu mereka berbuka dan bersuka ria atas nikmat Allah yang telah diberikan kepada mereka. Dan begitupula mereka saling mengucapkan selamat kepada saudara, kerabat, handai taulan dan para tetangganya. Oleh karena itu, pada hari raya ini diharamkan berpuasa, agar kaum muslimin seluruhnya menikmati hari raya ini (Hamid, 2003:105).
Menurut agama Kristen, hari raya Natal, Paskah, dan Pentekosta adalah bagian yang menonjul dari tahun liturgi Kristen. Banyak gereja mengikuti dan mendasarkan tahun liturgi mereka pada tiga lingkaran: Natal, Paskah, dan Pentekosta (Keene, 2006:114)

Menurut agama Hindu, hari raya artinya hari baik, suci atau keramat untuk melakukan Yajna ke hadapan Hyang Widhi, manifestasi-Nya, maupun paraleluhur. Melakukan upacara Yajna setiap hari (nitya karma), pada hari-hari suci, atau hari raya tertentu (naimitika karma) (Triguna, dkk, 2014:188).

Sedangkan dalam agama Budha, terdapat empat hari raya dalam Agama Budha. Namun satu-satunya yang dikenal luas oleh masyarakat adalah Hari Raya Waisak, sekaligus satu-satunya hari raya umat Buddha yang dijadikan hari libur nasional indonesi setiap tahunnya.

Budha mengajarkan bahwa manusia jangan mencari arti spiritual pada hari-hari raya. Maka, umat Budha tidak terlalu menilai hari-hari raya itu. Hal yang paling penting adalah sikap batin dari mereka yang merayakan (Keene, 2006:82).

Dalam agama Islam terdapat hari raya besar yaitu Hari Raya Idul Fitri, yang dilaksanakan secara berulang di setiap tahunnya dengan semangat kegembiraan, 
kebahagiaan, keceriaan dan senyum canda yang baru (Bahanan, dkk, 2002:211).

Hari Raya Idul Fitri ialah hari raya kaum muslimin yang dilaksanakan pada tanggal 1 Syawal (sesudah berakhirnya Ramadhan) (Glase, 1999:158). Ada kewajiban yang harus dilaksanakan sebelum menjalankan ibadah Idul Fitri, yaitu membayar zakat fitrah, di dalam agama Islam membayar zakat fitrah adalah satu hal yang wajib dilakukan umat Islam. Diberi nama id (hari raya) karena Allah SWT pada hari id itu memberikan berbagai ihsan kepada hamba-hamba-Nya pada setiap tahun. Di antaranya, di bolehkannya makan di siang hari setelah dilarang untuk makan di siang hari selama bulan Ramahdan, dan diperintahkan untuk menunaikan zakat fitrah. Karena biasanya, hari raya itu penuh dengan kebahagiaan, kesenagan dan berbagai aktivitas. Sementara keceriaannya kebanyakan terjadi karena sebab itu.Asal makna kata id sendiri secara bahasa adalah kembali, yaitu kembali dan berulangnya kebahagiaan setiap tahun (Al-Zuhaili, 2010:459).

Prof. T.M. Hasbi Ash Shiddieqy (1972:1) mengemukakan pendapatnya sebagai berikut: "id dalam pengertian bahasa sama dengan musim. Yakni musim manusia ramai-ramai berkumpul untuk merayakan sesuatu atau melaksanakan sesuatu. Kata 'id bermakna a'aid (yang kembali lagi), diambil dari pada kata 'aud, yang bermakna kembali kepada kesenangan, kegembiraan, memakai pakaian yang indah-indah, menikmati makanan-makanan yang lezat, seperti yang dilakukan pada hari itu dan kembali membersihkan hati dari dendam kesumat dari perangai-perangai yang keji, serta menghiaskan jiwa dengan kemesraan dan kasih sayang. dinamakan hari id dengan id. adalah karena dia selalu kembali pada saatnya dan karena pada hari itu banyak benar anugerah Allah SWT yang dicurahkan kepada hamba-hamba- Nya.

Dr. Ibrahim Anis (1972:635), memberikan keterangan tentang arti kata al id sebagai berikut:

"al-Id ialah apa yang kembali dari kesusaban atau penyakit atau kerinduan dan sebagainya. altid setiap hari berkumpul, dengan mengadakan peringatan terhadap sesuatu yang dianggap mulia atau sesuatu yang disayangi".

Zakat fitrah adalah zakat yang dikeluarkan oleh seorang muslim, baik kecil maupun besar, kaya maupun miskin, janda maupun duda, muda maupun tua, semuanya diwajibkan untuk mengeluarkan zakat fitrah berupa makanan pokok yang dikeluarkan setiap tahunnya sebelum selesai shalat Idul Fitri (Hamid, 2003:96).

Di dalam Islam terdapat beberapa hari besar Umat Islam, yaitu: Muharram, 
Hari besar Islam yang terdapat dalam bulan ini adalah tahun baru Islam yang dimulai dengan 1 Muharram. Di dalam bulan ini pula terdapat Asyura yaitu hari kesepuluh bulan Muharram yang disunnahkan berpuasa di dalamnya (Hamid, 2003:12).

Shafar. Bulan Shafar sering di sebut shafar al-khair, artinya bulan syafar yang penuh kebaikkan, maksudnya ialah bahwa penduduk jahiliyah selalu membenci bulan shafar bulan kebencian, maka Rasulullah membatalkannya, barangkali kebencian dan ketakutan itu, disebabkan oleh selesainya bulan haram, yang dilarang berperang dan kemungkinan besar perang yang akan terjadi bulan shafar dan kebiasaankebiasaan buruk (Hamid, 2003:24).

Rabiul Awal. Hari besar Islam bulan ini adalah tanggal 12 Rabiul Awal untuk memperingati kelahiran nabi Muhammad saw, yang lahir pada tanggal 12 Rabiul Awal tahun gajah, yakin pada tahun yang dikenal dengan penyerangan raja Abrahah dari Yaman yang akan menghancurkan ka'bah dengan pasukan bergajahnya, kemudian Allah mengirimkan burungburung Ababil yang menghancurkan mereka dan Allah menjaga Ka'bah dari kedzaliman mereka (Hamid, 2003:28).

Rabiul Tsani. Tidak ada hari besar dalam bulan Rabiul Tsani.namun demikian banyak perisstiwa penting yang terjadi pada bulan ini. Salah satunya ialah pengepungan Damaskus ( 14H/635 M) Pengepungan berlangsung dibawah pimpinan $\mathrm{Abu}$ Ubaidah bin al-Jarah (Hamid, 2003:36).

Jumadal Ula. Peristiwa penting banyak terjadi dibulan ini, salah satunya, terjadi pembukaan kota Constantinopel, ibu kota kekuasaan Byzantium $(857 \mathrm{H}$, 29/5/1453). dibawah pimpinan Sulthon Muhammad (Hamid, 2003:38).

Jumadal Tsani. Peristiwa yang terjadi dibulan ini, salah satunya, dibaiatnya Umar bin Khattab sebagai khalifah pada tahun 13 H/ 643 M (Hamid, 2003:40).

Rajab. Rajab berarti kemuliaan, rajabun murajjab artinya bulan Rajab yang dimuliakan. Dinamakan bulan Rajab dikarenakan sejak dulu kala, pencucian ka'bah dilakukan pada bulanini, sehingga bulan ini dinamakan bulan Rajab (Hamid, 2003:42).

Sya'ban. Sya'ban adalah bulan antara Rajab dan Ramadhan yang memiliki peranan persiapan menghadapi ibadah bulan puasa dibulan Ramadhan dan akhir bulan untuk meninggalkan kebiasaan makan dan minum di bulan-bulan sebelumnya (Hamid, 2003:56).

Ramadhan. Dibulan ini banyak peristiwa-peristiwa penting di dalamnya yang patut diketahui oleh umat Islam, yaitu: ibadah puasa, Nuzul Qur'an yang jatuh 
setiap 17 Ramadhan, Lailatul Qadar (Hamid, 2003:60).

Syawal. Pada bulan ini terdapat hari raya umat Islam yang jatuh pada setiap tanggal 1 syawal. Hari raya ini kita kenal dengan Idul Fitri. Hari raya ini merupakan hari kebahagiaan bagi kaum muslimin telah menempuh ujian puasa selama 1 bulan. Dan yang perlu di ketahui dari rangkaian ibadah dalam bulan syawal ini adalah, takbir, shalat Idul Fitri dan Tabarruk atau halal bihalal (Hamid, 2003:103).

Dzulqadah. Bulan ini adalah bulan masuknya haji, karena itu kaum muslimin yang hendak melaksanakan haji telah berangkat kemekkah guna melaksanakan umrah atau hajinya, dan saat ini pula kaum muslimin dari seluruh dunia memenuhi kota madinah dan makkah sebagai dua kota suci umat Islam (Hamid, 2003:125).

Dzulhijjah. Hari sebar umat Islam pada bulan ini adalah hari raya Idul Adha. Pada hari ini umat Islam disyariatkan dengan ibadah qurban yakni menyembelih kambing, sapi atau unta sebagai bukti ketaatan mereka kepada allah. Syariat qurban ini pada dasarnya untuk membagi kebahagiaan kepada orang lain (Hamid, 2003:129).

Diatas dapat kita simpulkan bahwa di dalam agama Islam terdapat bulan-bulan Islam yang memiliki hari-hari besar tersendiri yang mempunyai kejadian yang menjadi sejarah umat Islam.

Hinduisme merupakan agama yangmempunyai banyak perayaan meskipun sebagian besar hanya dirayakan secara lokal. Perayaan dipandang sebagai usaha untuk memberikan jaminan terhadap kelanggengan tradisi Hindu dan membantu anak-anak untuk mengetahui dewa-dewi.

Galungan jatuh setiap Rabu Kliwon Dungulan adalah hari Pewedalan Jagat yaitu pemujaan bahwa telah terciptanya jagat. Persembahan dan pemujaan terhadap Hyang Widhi, dilakukan dengan penuh kesucian dan ketulusan hati, memohon kebahagiaan hidup dan agar dapat menjauhkan dari awidya. Galungan adalah perlambangan perjuangan antara yang benar (Dharma) melawan yang tidak benar (adharma), dan juga sebagai pernyataan terimakasih atas kemakmuran dalam alam yang diciptakan Hyang Widhi ini (Keene, 2006:30).

Perayaan keagamaan Hindu dapat dibagi menjadi tiga kelompok : Pertama, Perayaan menurut penanggalan Hindu. Kelompok ini mengikuti pola enam musim dalam setahun atau sepanjang 354 hari. Masing-masing musim semi (Maret-Juni), musim panas (Mei-Juli), musim hujan (JuliSeptember), musim gugur (SeptemberNovember), musim dingin (November- 
Januari), musim gembira (Januari-maret) (Keene, 2006:30).

Kedua, Perayaan yang berhubungan dengan musim bercocok tanam. Kelompok ini terdiri dari perayaan yang berhubungan dengan musim khusus dalam tahun musim tanam. Negara yang tergantung pada pertanian, musim menabur benih dan musim panen adalah saat yang paling vital sepanjang tahun. Navaratri, "perayaan sembilan malam", adalah perayaan masa tabur benih untuk pemanen musim dingin. Ketika perayaan dimulai, beberapa bijij jawawut ditaburkan di atas pinggan kecil supaya kelak biji itu dapat mulai bertunas (Keene, 2006:31).

Kedua, Mela. Kelompok ini adalah perayaan peristiwa-peristiwa penting di dalam legenda Hindu yang dikenal dengan istilah mela. Kumbh Mela dilaksanakan setiap dua tahun sekali dan berkisar pada empat macam hal, yaitu Haridwar, Nasik, Prayoga, dan Ujjain. Mitos di balik perayaan ini adalah perang antara para dewa dengan roh-roh jahat di atas suatu buyung yang menyimpan minuman kehidupan kekal. Para dewa menang, tetapi selama peperangan ada empat tetes minuman kehidupan kekal itu jatuh menumpahi tempat di mana Kumbh Mela dilaksanakan (Keene, 2006:31).
Disamping itu hari raya digunakan pula untuk menyatakan terimakasih dan rasa bahagia atas kemakmuran Hyang Widhi yang dibayangkan telah sudi turun diiringi oleh para Dewa-Dewa dan PitaraPitara ke dunia. Sehari sebelum Galungan yang pada hari Anggara Wage Dungulan dinamai Penampahan, mulai saat mana segala nafsu harus dihilangkan dalam badan sebelum menyambut hari suci besoknya. Manusia dilahirkan dalam keadaan awidya (kegelapan), yaitu sifat nafsu murka, iri hati, congkak, angkara. Semua sifat ini disimbolkan dengan Sang Kala Tiga atau kejahatan yang tiga, diberi Gelar Sang Bhuta Galungan, Butha Dungulan, Butha Amangkurat (Keene, 2006:195).

Hari Raya Keagamaan dalam Agama Hindu : Hari raya Nyepi. Hari raya nyepi adalah hari tahun baru saka, jatuh sehari sesudah Tilem kesanga, penanggal 1 sasih Kedasa. Pada bulan mati sebulan maret yaitu peralihan pergantian tahun baru Isaka adalah hari pengerupukan diadakan upacara bhuta yadnya tawur agung untuk menghilangkan unsur-unsur kejahatan yang merusak kesejahteraan umat manusia (Triguna, dkk., 2014:192).

Hari raya Siwaratri. Siwaratri berarti "malam renungan suci" atau "malam peleburan dosa" untuk memperoleh mengampunan dari Sang Hyang Widhi atas 
dosa yang disebabkan oleh awidya (kegelapan/kebodohan).

Dilakukan semalam suntuk pada waktu prewanining tilem ke-VII, (Kepitu) sehari sebelum bulan mati sekitar bulan januari, dengan menjalankan yoga semadhi atau membacabaca pustaka suci dan berpuasa. (Triguna, dkk., 2014:193).

Hari raya Saraswati. Hari raya untuk memuja Hyang Widhi dalam kekuatan menciptakan ilmu pengetahuan dan ilmu kesucian. Jatuh setiap sabtu Umanis Wuku Watugunung dan renungan isi ajaran pustaka suci, dalam manifestasinya ini dilambangkan seorang Dewi yang membawa alat musik, genitrim pustaka suci, teratai serta duduk diatas angsa (Triguna, dkk., 2014:193).

Hari raya Pagerwesi. Pagerwesi setiap hari Rabu Kliwon Wuku Sinta, adalah pemujaan Hyang Widhi dengan perbhawanya sebagai Hyang Pramesti Guru yang sedang beryoga untuk kesentosaan alam ciptaannya dengan diiringi oleh para Dewa, Pitara-pitara (Triguna, dkk., 2014:194).

Hari Galungan. Galungan adalah perlambangan perjuangan antara kebaikan (Dharma) melawan keburukan (Adharma), dan juga sebagai pernyataan terimakasih atas kemakmuran dalam alam yang diciptakan Hyang Widhi ini (Triguna, dkk., 2014:194).

Hari Kuningan. Hari kuningan muncul sepuluh hari setelah lewatnya Galungan, sabtu kliwon Kuningan, hari kembalinya SangPitara bersama para Dewa dimana umat menghaturkan bhakti memohon kesentosaan, dan panjang umur serta perlindungan dan tuntunan lahir batin selalu (Triguna, dkk., 2014:195).

\section{Idul Fitri}

\section{Sejarah Idul Fitri}

Pada bulan syawal terdapat hari raya bagi umat islam yang jatuh pada setiap tanggal 1 syawal. Hari raya ini kita kenal dengan Idul Fitri. Hari raya ini merupakan hari kebahagiaan bagi kaum muslim setelah menempuh ujian puasa selama satu bulan. Dan yang diperlu diketahui dari rangkaian ibadah dalam bulan syawal ini adalah; takbir, shalat idul fitri dan tabarruk atau halal bihalal (Hamid, 2003:103).

Asal mula terjadinya Hari Raya Idul Fitri pada masa Rasulullah SAW, disebuah kota yang terletak di Madinah ada dua hari yang didalamnya terdapat kaum-kaum Yatsrib yang menggunakan dua hari tersebut dengan berpesta-pesta dan bersenang-senang semata, yang terkesan berfoya-foya. Kedua hari 
tersebut di namakan hari An-Nairuz dan hari Al-Muhrajan (Bahanan, dkk, 2002:2014).

Ketika hal tersebut menjadi sebuah tradisi dan budaya kaum Yasyrik, sampailah kabar tersebut pada Rasulullah SAW. Sehingga ingin mencari tahu, bahwa apa yang sedang mereka lakukan dengan kedua hari tersebut. Kemudian orang-orang Madinah pun menjawab : "Wahai Rasul pada hari ini kami sedang merayakan pesta untuk kesenangan dan kepuasan kita dan kita akan menjadikan hari ini menjadi sebuah tradisi kita karena hari ini sudah ada sejak zaman kaum Jahiliyah" (Bahanan, dkk, 2002:75-76).

Mendengar hal tersebut Rasullah kaget dan tersentak hatinya untuk menyuruh mereka berhenti melakukan hal yang tidak bermanfaat. Sehingga kemudia Rasulullah berkata kepada kaum Yasyrik tersebut, kalian harus tahu bahwa sesungguhnya Allah menggantikan kedua hari tersebut dengan hari yang lebih baik dari pada sekedar berpesta-pepsta yang hanya akan menjadikan kalian kaum yang bodoh yang akan menggunakan waktu dan harta kalian dengan mubazir atau sia-sia. Sesungguhnya Allah SWT telah menggantikan kedua hari tersebut dengan Hari Raya Idul Fitri dan Idul Adha, yang penuh dengan makna dan hikmah-hikmahnya. (Bahanan, dkk, 2002:77)

Peristiwa tersebut menjadi sebuah riwayat Hadist yang terdapat di kitab Fiqh Madzahib Al-Arbaah:

"Ketika Nabi shallallabu 'alaibi wa sallam datang ke Madinah, penduduk. Madinah memiliki dua hari raya untuk bersenang-senang dan bermain-main di masa jabiliyah. Maka belian berkata, "Aku datang kepada kalian dan kalian mempunyai dua hari raya di masa Jabiliyah yang kalian isi dengan bermainmain. Allah telah mengganti keduanya dengan yang lebih baik bagi kalian, yaitu hari raya Idul Fithri dan Idul Adha (hari Nabr)" (HR.An Nasai no. 1556 dan Abmad 3: 178, sanadnya shabih sesuai syarat Bukhari-Muslim sebagaimana kata Syaikh Syu'aib Al Arnauth".

Jadi dari hadist diatas dapat diketahui bahwa Rasulullah Saw, tidak menganjur untuk melakukan 2 hari tersebut dengan berfoya-foya dan bersenang-senang saja, tetapi Rasulullah saw menggantikan kedua hari raya yang dilakukan kaum Yasyrik itu dengan hari raya Idul Adha dan Idul Fitri yang masing-masingnya memiliki makna dan manfaatnya.

Disuatu hari raya Rasulullah shallallahu'alaihi wasallam keluar rumah untuk melaksanakan shalat Idul Fitri. Sementaraanak-anak kecil tengan 
bermain riang gembira di jalanan. Tetapi tampak seorang anak kecil duduk menjauh berseberangan dengan mereka. Dengan pakaian sangat sederhana dan tampak murung, ia menangis tersedu (Usman bin Hasan, tth:264).

Melihat fenomena ini Rasulullah segera menghampiri anak tersebut. "Nak, mengapa kau menangis? Kau tidak bermain bersama mereka?” Rasulullah membuka percakapan. Anak kecil yang tidak mengenali bahwa orang dewasa di hadapannya adalah Rasulullah, dan ia menjawab "Paman, ayahku telah wafat. Ia mengikuti Rasulullah dalam menghadapi musuh disebuah pertempuan. Tetapi ia gugur dalam medan perang tersebut". Rasulullah Shallallahu'alaihi wasallam terus mengikuti cerita anak yang murung tersebut sambil meraba kemana ujung cerita, Nabi mendengarkan dengan seksama rangkaian peristiwa dan nasib malang yang menimpa anak tersebut (Usman bin Hasan, tth:264).

"Ibu ku menikah lagi. Ia memakan warisanku, peninggalan ayah. Sedangkan suaminya mengusirku dari rumahku sendiri. Kini aku tak memiliki apapun. Makanan, minuman, pakaian, dan tempat tinggal. Aku bukan siapa-siapa. Tetapi hari ini aku melihat teman-teman sebayaku merayakan hari raya bersama ayah mereka. Dan perasaanku dikuasi oleh nasib kehampaan tanpa ayah. Untuk itulah aku menangis".

Mendengar penuturan ini, batin Rasulullah terenyuh. Ternyata ada anakanak yatim dari sahabat yang gugur membela agama dan Rasulnya di medan perang mengalami nasib malang begini. Rasulullah segera menguasi diri. Rasul yang duduk berhadapan dengan anak ini segera menggenggam lengannya. "Nak, dengarkan baik-baik. Apakah kau sudi bila aku menjadi ayahmu, Aisyah menjadi ibumu, Ali sebagai paman, Hasan dan Husein sebagai saudara, dan Fatimah sebagai saudarimu?" tanya Rasulullah. Mendengar tawaran itu, anak ini mengerti seketika bahwa orang dewasa di hadapannya tidak lain adalah Nabi Muhammad SAW. "Kenapa tidak sudi, ya Rasulullah?” jawab anak ini dengan senyum, terbuka. Rasulullah kemudian membawa anak angkatnya pulang kerumah. Disana anak ini diberi pakaian terbaik. Ia dipersilahkan makan hingga kenyang, penampilannya diperhatikan lalu diberikan wangiwangian. Setelah beres semuanya, ia pun keluar dari rumah Rasulullah dengan senyum dan wajah bahagia. Melihat perubahan drastis pada anak ini, para 
sahabatnya bertanya. "Sebelum ini kau menangis, tetapi kini kau tampak sangat gembira?". "Benar sahabatku. Tadinya aku lapar, tetapi lihatlah, sekarang tidak lagi. Aku sudah kenyang. Dulunya aku memang tidak berpakaian, tetapi kini lihatlah. Sekarang aku mengenakan pakaian bagus. Dulu memang aku ini anak yatim, tetapi sekarang aku memiliki keluarga yang sangat perhatian. Rasulullah SAW ayahku, Aisyah ibuku, Hasan dan Husein saudaraku, Ali pamanku, dan Fatimah adalah saudariku, apakah aku tidak bahagia?” (Usman bin Hasan, tth:264).

Mendengar sahabatnya, mereka tampak menginginkan nasib serupa. "Aduh, cobalah ayah kita juga gugur pada peperangan itu sehingga kita juga diangkat sebagai anak oleh Rasulullah SAW" (Usman bin Hasan, th:265). Waktu terus berjalan. Usia semakin bertambah. Kebahagiaan anak ini pun lenyap ketika selang beberapa tahun setelah itu Rasulullah SAW meninggal dunia. Meratapi kepergian ayah angkat paling mulia ini, ia keluar rumah seraya menaburkan debu diatas kepalanya (Usman bin Hasan, tth:265).

"Celaka, sungguh celaka. Kini aku kembali terasingi. Aku bukan siapa-siapa lagi. Aku ini menjadi yatim. Sepi" katanya terisak. (Usman bin Hasan, tth:264).

Itulah makna yang penting akan kepedulian kita terhadap orang disekitar kita, termasuk dalam menyayangi orangorang yang membutuhkan terutama anak yatim.

\section{Tata cara pelaksanaan Idul Fitri}

Hari raya umat Islam ini merupakan kemenangan bagi orangorang yang berpuasa. Oleh karena itu pada waktu matahari ternggelam dan menandakan akhir dari bulan Ramadhan, kaum muslimin mengisi waktu tersebut dengan mengucapkan takbir dan tahmid. Pada pagi harinya melaksanakan shalat Eid (Hamid, 2003:106).

Waktu shalat Idul Fitri adalah sejak terbitnya matahari sekitar tiga meter dari tenggelamnya, seperti diriwayatkan oleh ahmad bin hasan Al-Banna, dari hadist jundab berkata (Hamid, 2003:106): "Nabi Mubammad SAW, disebutkan shalat Idul Fitri bersama kami dan matahari berada sekitar dua tombak, dan adha sekitar satu tombak (satu tombak disamakan dengan tiga meter)". Dan disunnahkan ta'khier shalat ied agar orang yang belum berzakat dapat melaksanakan kewajibannya (Hamid, 2003:106). Sesuai dengan sabda Rasulullah SAW : 
Artinya: "Dari Yazid bin Humair arRababi, "Abdullab bin Busr $\mathrm{RA}$, sahabat Rasulullah SAW pernah keluar bersama orang banyake untuke shalat Idul Fitri atau Idul Adha. Beliau tidak. membenarkan keterlambatan imam, lalu berkata, 'sesunggubnya kami biasanya pada saat ini telah selesai.Saat itu adalah waktu Dhuba".

Di bulan inilah umat Islam melaksanakan kewajibannya yaitu menunaikan pembayaran zakat fitrah. Pada dasarnyaa zakat sangatlah dianjurkan dalam Al-Qur'an (AlBaqarah : 110) : Dan dirikanlah shalat dan tunaikanlah rakat, dan kebaikean apa saja yang kamu usahakan bagi dirimu, tentu kamu akan mendapatkean pahalanya pada sisi Allah. Sesunggubnya Allah Maha melihat apa yang kamu kerjakan.

Jadi, untuk menyempurnakan ibadah selama bulan puasa, umat islam diwajibkan membayar zakat firah. Hal ini dinilai sebagai pembersih dari halhal yang mengotori puasa.

Shalat Idul Fitri di dalam masjid tidaklah makruh, tetapi pelaksanaannya diluar masjid itu lebih afdhal, selain makkah, karena shalat di Masjidil Haram lebih baik, bila tidak ada udzhur dan sebagainya. Karena Rasulullah saw, melaksanakan shalat eid di lapangan (dan beliau tidak pernah shalat di masjidnya kecuali ketika turun hujan) (Hamid, 2003:106).
Disyariatkan kepada anak anak wanita untuk keluar ke lapangan pada hari raya tersebut, tidak ada perkecualian baik perawan maupun janda, nenek-nenek dan tua renta bahkan orang yang haid. Hal tersebut sesuai dengan hadist yang disampaikan oleh Ummi Atiyyah bahwa ia berkata : "Kami diperintahkan untuk mengeluarkan perawan-perawan, orang haid, dalam dua hari raya (Idul Fitri dan Idul Adha), agar mereka melihat kebaikan dan dakwah kaum muslimin dan orang yang haid tidak melakukan shalat (HR. Muttafaq alaihi) (Hamid, 2003:107).

Hadist yang membahas tentang hari raya idul fitri adalah hadist nomor 905 :

Telah menceritakan kepada kami (ibrabim bin musa) berkata. Telab mengambarkan kepada kami (bisyam) bahwa (ibnu juraiji) telah mengambarkan kepada mereka, ia berkata; telab mengambarkan kepadaku (Atha) dari (jabir bin Abdullab) berkata, aku mendengarnya berkata, "Rasullulah Shallallabu 'alaibi wasallam keluar pada hari Raya idul fitri, beliau memulainya dengan shalat kemudian khutbah."

Shalat 'idul fitri dan shalat idul adha dua shalat yang dilakukan di lapangan terbuka (bila memungkinkan) pada dua hari raya. Hukum shalat 'Ied 
adalah sunah mu'akkadah. Bahkan kaum perempuan yang sedang haid pun disunnahkan untuk bisa hadir di tempat shalat, walaupun tidak ikut shalat. Tata cara shalatnya memiliki kesamaan, hanya pada beberapa perbuatan sunnah tertentu di luar shalat yang berbeda. Adapun Pelaksanaan shalat Idul Fitri adalah:

Sebelum salat Ied, disunnahkan untuk memperbanyak bacaan takbir, tahmid, dan tasbih. Salat Ied dimulai dengan menyeru "ash-shalâtu jâmi'ab" yang artinya "Salat jama'ah akan segera didirikan. Selain itu, salat Ied dilaksanakan tanpa didahuli azan dan iqamah. Membaca niat salat Idulfitri. Sebagaimana ibadah-ibadah lainnya, salat Idulfitri juga mesti didahului dengan niat. Membaca takbiratul ihram (الله أكبر/Allahu Akbar) sambil mengangkat kedua tangan. Tujuh takbir pada rakaat pertama. Pada rakaat pertama salat ied, setelah membaca doa iftitah, dilanjutkan dengan membaca takbir lagi sebanyak tujuh kali. Takbir sebanyak tujuh kali tersebut diucapkan sambil mengangkat tangan. Di sela-sela setiap dari tujuh takbir itu dianjurkan membaca: "Subhanallah wal hamdulillah walaa ilaaha illallah wallahu akbar." Membaca Surah
al-Fatihah. Setelah takbir tujuh kali, kemudian membaca surah alFatihahsebagai rukun salat.Setelah itu, disunahkan membaca surah al-A'la. Kemudian dilanjutkan dengan ruku', iktidal, sujud, duduk di antara dua sujud, dan sujud kedua, seperti salat biasa. Lalu, berdiri kembali untuk melaksanakan rakaat kedua. Lima takbir pada rakaat kedua Selepas berdiri lagi pada rakaat kedua, membaca takbir lagi sebanyak 5 kali sambil mengangkat tangan seperti sebelumnya. Kelima takbir itu di luar takbir saat berdiri pada rakaat kedua (takbir qiyam). Di sela-sela setiap dari lima takbir itu dianjurkan membaca: "Subhanallah wal hamdulillah walaa ilaaba illallah wallabu akbar". Setelah lima takbir, membaca surah al-Fatihah, dan kemudian disunahkan membaca surah al-Ghasyiyah. Kemudian dilanjutkan dengan rukuk, Iktidal, sujud, duduk di antara dua sujud, sujud kedua, duduk tasyahud akhir dan salam. Setelah salat, mendengarkan khutbah Idulfitri.

Usai shalat Idulfitri, khatib membacakan khutbah hari raya dan jamaah sebaiknya mendengarkan dengan khusuk. Sedangkan apabila jumlah jamaah kurang dari empat orang atau jika dalam pelaksanaan 
shalat Id berjamaah di rumah tidak ada yang berkemampuan untuk khutbah, salat Idulfitri boleh dilakukan tanpa khutbah.

Pelaksanaan Idul Fitri tidak pula diketahui dengan adzan ataupun iqamah, tetapi langsung shalat ied dan dilanjutkan dengan khutbah. Ibnul Qayyim berkata : Rasulullah saw, bila telah sampai ditempat shalat. Beliau langsung shalattanpa adzan dan iqamah. Tidak juga kata-kata asshalaatu jaamiah, sunnahnya ialah tidak melakukan hal tersebut. Dan dari atha berkata: "aku telah diberitakan Jabir bahwa hari Idul Fitri tanpa adzan, ketika imam telah keluar, atau ia selesai, tidak ada iqamah dan seterusnya" (HR. Muslim) (Hamid, 2003:107).

Shalat Eid dua rakaat, disunnahkan bertakbir didalamnya sebelum pembacaan Al-Fatihah pada rakaan pertama, 7 takbir setelah takbiratul ihram rakaat pertama, dan 5 kali takbir setelah raka'at kedua, dengan mengangkat kedua tangan setiap takbir (Hamid, 2003:108).

Kemudian membaca iftitah dan al-fatihah setelah takbir, yang lebih tepat, para ahli dari sahabat, tabi'in dan para imam mengambir pendapat ini. Kemudian Rasulullah diam antara dua takbir sebentar, dan baiknya membaca diantara takbir (Hamid, 2003:108).

Dan mengenai shalat Qabliyah atau ba'diyah tidak diitetapkan dalam shalat ied. Berkata Ibnu Abbas : Rasulullah saw, keluar pada hari ied dan shalat dua rakaat, beliau tidak shalat sebelumnya atau sesudahnya (HR. Jamaah) (Hamid, 2003:109).

Sedangkan apabila tidak jelas datangnya satu Syawal karena adanya awan ataupun karena hujan, maka diambillah kesimpunlan untuk menyempurnakan bulan Ramadhan tiga puluh hari. Apabila ternyata terdapat bukti bahwa setelah kaum muslimin tidak melihat bulan karena tertutup awan atau hujan, sedangkan pada hari itu terdapat orang yang membuktikan bahwa satu Syawal telah masuk maka kaum muslimin berbuka puasa pada hari itu (Hamid, 2003:109).

\section{Makna dan Tujuan Idul Fitri}

Makna dan tujuan Idul Idul Fitri memiliki arti penting bagi umat islam di dunia, karena pada hari tersebut umat islam merayakannya karena telah menyelesaikan puasa Ramadhan selama satu bulan penuh. Di Indonesia perayaan hari raya Idul 
Fitri ini dilakukan selaras dengan kebudayaan yang ada. Perayaan ini pun di laksanakan dengan penuh suka cita, dan masyarakat juga menggemakan takbir dan melaksanakan shalat Ied, Idul Fitri juga merupakan momen yang sangat bermanfaat karena dihari itu umat Islam memanfaatkannya dengan cara bersilaturahmi terhadap keluarga maupun tetangga.

\section{Galungan}

\section{Sejarah Galungan}

Galungan adalah hari Perjuangan Dharma melawan Adharma yaitu pemujaan bahwa telah terciptanya kemenangan kebenaran atas ketidakbenaran dengan restu Sang Hyang Widhi. Hari ini muncul tiap-tiap 6 bulan (210 hari) sekali yaitu pada hari Rabu Kliwon Wuku Dungulan. Persembahan dan pemujaan terhadap Sang Hyang Widhi, dilakukan dengan penuh kesucian dan ketulusan hati, memohon kebahagiaan hidup dan agar dapat menjauhkan diri dari awidya.

Galungan adalah perlambang perjuangan antara yang benar (Dharma) melawan yang tidak benar (Adharma), dan juga sebagai pernyataan terima kasih atas kemakmuran di alam yang diciptakan Tuhan ini (Sudharta dan Atmaja, 2010:40).

Hari Raya Galungan dan Kuningan yaitu setiap hari Budha Kliwon Wuku Dungulan yang merupakan pemujaan kepada Hyang Widhi dalam berbagai aspeknya dan juga keapada roh leluhur (Triguna, dkk, 2014:163).

Dalam perhitungan Wuku dungulan terdapat Pawukon Saka yang artinya jenis pawukon yang dipadukan dalam Kalender Saka. Jenis pawukon lainnya adalah Pawukon Jawa dan Pawukon Bali. Salah satu contoh penggunaan Pawukon Saka adalah pada Prasasti Sang Hyang Tapak (Cicatih/Jaya Bupati) yang ditemukan di Sukabumi, Jawa Barat dan berangka tahun 952 Saka (1030 Masehi). Saat itu, masyarakat Jawa telah mengembangkan pengetahuan matematika (sebut sebagai Matematika Jawa) yang digunakan untuk menciptakan Pawukon Saka (Prabowo, 2015).

Pawukon merupakan hitungan waktu yang berlangsung selama 210 dan terbagi menjadi 30 kali siklus tujuh harian. Siklus tujuh harian ini disebut wnku. Meskipun umur setiap wnku tujuh hari dan pergantian wuku mengikuti selesainya siklus saptawara, wuku bukan mingguan. Oleh karena 
pergantian wuku setiap tujuh hari, maka banyaknya wuku adalah 30 buah. Jumlah 210 hari dalam Pawukon Saka berasal dari siklus bersama 5, 6, dan7 hari dari tiga jenis wewaran. Jenis wewaran yang pertama kali digunakan adalahsaptawara (654 Saka), disusul dua jenis wewaran sekaligus (pancawara dansadwara, 714 Saka). Penggunaan nama wuku yang menandakan Pawukon barudigunakan pada tahun 952 Saka terpahat di Prasasti Cicatih. Fakta ini menjelaskanbahwa Pawukon telah digunakan pada tahun 1030 Masehi.Pawukon Saka yang dibangun oleh pancawara, sadwara, saptawara dan30 buah wuku diciptakan dengan aritmatika yaitu modulo 5, 6 dan 7 sehinggaPawukon Saka dapat disebut sebagai mathematical calendar. Hari pertamaPawukon Saka adalah RaditePaing, Tungle, wuku Sinta.Aturan untuk menentukan nama hari suatu wewaran (pancawara,sadwara, dan saptawara) menggunakan aritmatika berdasarkan Modulo Jawa pada nomor urut hari Pawukon (Prabowo, 2015).

Wuku dungulan, Wuku memiliki peran penting dalam perhitungan pendewasan. Satu tahu wuku panjangnya 420 hari, terdiri dari 30 wuku (210 hari) dikalikan dua. Setiap wuku (1 wuku) panjangnya 7 hari, terhitung dari : Redite, Coma, Anggara, Budha, Wrhaspati, Sukra dan Saniscara. Sebulan dalam tahu wuku dibangun menjadi 5 wuku. Jadi 1 bulan dalam tahun wuku panjangnya 35 hari, didapat dari pengkalian 7 hari dengan 5 wuku. Satu peredaran wuku (30 wuku) termasuk 6 bulan dalam tahun wuku, 6 bulan ini didapat dari mengalikan jumlah hari dalam sewuku dengan jumlah wuku (7 hari x 30 wuku= 210). 1 tahun wuku terdiri dari 2 kali perdara wuku, yakni 7 hari x 30 wuku x $2=420$ hari (Triguna, dkk, 2014:163).

Oleh karena itu, perayaan hari raya Galungan di dalam Agama Hindu muncul pada 6 bulan sekali atau 210 hari, untuk memperingati rasa syukur umat Hindu terhadap Hyang Widhi Wasa.Hari Raya Galungan adalah pemujaan kepada Sang Hyang Widhi atas karunianya kepada umat manusia sehingga dapat hidup tentram, damai, sejahtera lahir dan batin.

Terdapat banyak perayaan agama yang bermakna sama dari agama yang berbeda. Mencari persamaan dalam kehidupan berbangsa yang beraneka ragam suku, agama dan ras sangat perlu demikian juga perlu mencari perbedaan untuk menemukan persamaan.Dari 
beberapa persamaan makna suatu perayaan keagamaan salah satunya adalah Idul fitri dan Galungan. Hari Raya Idul Fithri merupakan puncak dari seluruh rangkaian proses ibadah selama bulan Ramadhon. Idul Fitri disebut-sebut sebagai 'Hari Kemenangan', menurut Zainul Alim (2012) hari raya Idul Fitri dan kemerdekaan Indonesia mempunyai falsafah yang sama yaitu simbol kemerdekaan dan hari kemenangan. Mengapa Idul Fitri disebut-sebut sebagai 'Hari Kemenangan' ? Jawaban atas pertanyaan ini bisa ditelusuri melalui 2 (dua) pengertian berikut ini ( Idul Fitri Hari Kemenangan, Pertama, dari kata idul fithri itu sendiri yang berarti kembali ke fitrah, yakni 'asal kejadian', atau 'kesucian', atau 'agama yang benar'. Maka setiap orang yang merayakan idul fitri dianggap sebagai cara seseorang untuk kembali kepada ajaran yang benar, sehingga dia bisa memperoleh kemenangan. Kedua, dari kata 'minal 'aidin wal faizin' yang berarti 'semoga kita termasuk orangorang yang kembali memperoleh kemenangan' .Karena menurut para ahli, kata al-faizin diambil dari kata fawz, sebagaimana tersebut dalam AlQur'an, yang berarti 'keburuntungan' atau 'kemenangan'. Makna yang sama sebagai hari kemenangan bagi umat Hindu adalah hari raya Galungan, hari raya galungan jatuh pada hari Budha Kliwon wuku Dungulan

Hari raya yang dirayakan oleh umat Hindu yang penting adalah: Nyepi (Tahun baru) Siwaratri, Saraswati, Pagerwesi, Galungan, Kuningan. Diantara hari-hari suci ini hari raya Nyepi (tahun baru) Siwaratri dan Saraswati dirayakan di seluruh dunia dimana saja umat Hindu berada.

\section{Tata cara pelaksanaan Galungan}

Ada beberapa rangkaian pelaksanaan dari hari raya Galungan, diawali dengan : Pertama, Tumpek Wariga. Tumpek wariga yaitu 25 hari sebelum hari raya galungan yang jatuh setiap Saniscana (sabtu) kliwon wuku wariga. Tumpek wariga juga disebut Tumpek Pengatan, Pengarah, Bubuh dan Uduh. Pada hari Tumpek Wariga ini umat Hindu menghaturkan sesajen untuk pemujaan yang diberikan kepada dewa sangkara atau yang biasa di sebut dengan Dewa tumbuhtumbuhan. Adapun isi dari sesajen tersebut berisi bubur sumsum yang melambangkan kesuburan atau untuk memohon keselamatan kepada tumbuh-tumbuhan agar Hindu dengan 
sempurna dan dapat memberikan hasil untuk melakukan perayaaan hari raya galungan (Sujana dan Susila, 2012:79).

Kedua, Sugiyah Jawa. Hari Sugiyah Jawa diperingati setiap 210 hari atau 6 bulan sekali pada Wraspati (kamis) Wage Wuku Sungsang atau 6 hari sebelum perayaan hari raya Galungan. Sugiyah Jawa ini biasa disebut dengan hari Pamrascitang (pembersihan). Pada hari Sugiyah Jawa ini umat Hindu memohon kesucian terhadap alam semesta Bhuwana Agung, dan melakukan pensucian terhadap tempat-tempat suci dan perumahan, adapun pensucian ini dilakukan dengan berkaladan niskala.

Ketiga, Sugihan Bali. Hari Sugihan Bali diperingati setiap 210 hari atau 6 bulan sekali setiap sukra (jumat) kliwon Wuku Sungsang atau 5 hari sebelum peringatan hari Galungan. Pada hari Sugihan Bali ini umat Hindu memohon kesucian terhadap dirinya sendiri (Bhuwana Alit). Upacara Sugihan Bali ini dilakukan memohon Tirtha penglukan pada sang sadaka atau Salinggih sesuai dengan persembayangannya.

Untuk hari Sugihan Bali, sebagai waktu yang ditujukan bagi pensucian bhuana alit, yaitu bagi diri kita sendiri-
sendiri.Dapat dilakukan dengan melaksanakan upawasa semampunya, maupun dengan melaksanakan persembahyangan baik di rumah maupun di tempat suci.Dapat pula dengan melakukan samadhi, untuk menenangkan pikiran dalam menyambut datangnya hari kemenangan dharma atas adharma.Sloka dari pustaka suci Manawa Dharma Sastra berikut ini, dapat pula dijadikan pedoman dalam pelaksanaan Sugihan Bali. Adapaun bunyinya sebagai berikut: Adbirgaatrani suddhyati, Manah satyena suddhyati, Vidya tapobhyam bhutaatma, Buddhir jnyanena sudhyati Terjemahannya Badan dibersihkan dengan air, Pikiran disucikan dengan kebenaran dan kejujuran, Atman disucikan dengan ilmu pengetahuan dan Tapa, Budhi disucikan dengan kebijaksanaan. (Manawa Dharmasastra V.109) Bunyi sloka tersebut, memberi kita suatu tuntunan tindakan yang dapat ditempuh dalam usaha-usaha yang diperuntukan bagi pencapaian kesucian atau kebersihan dari diri kita sendiri, baik secara sekala maupun niskala, dan secara jasmani maupun rohani.Bertolak dari bunyi sloka tersebut, maka sebenarnya penerapan 
konsep atau tattwa dari hari raya

Sugihan ini, dapat dilaksanakan dalam kehidupan sehari-hari.Konsep kesucian ini dapat meningkatkan kualitas hubungan sosial kita secara horisontal yakni dengan sesama dan juga dengan lingkungan alam kita.Maupun kualitas hubungan rohani kita secara vertikal dengan Brahman.Upacara yang bersifat khusus boleh dikatakan tidak ada dan agar diusahakan mohon tirta penglukatan kehadapan Sang Sadaka atau Sulinggih disamping bersembahyang serta mohon tirta sebagaimana biasa pada hari-hari Kliwon.

Keempat, Hari Penyekeban. Hari penyekeban dilaksanakan setiap hari Minggu/ Radite Pahing Wuku Dungulan atau 3 hari sebelum perayaan hari Galungan. Pada hari Penyekeban ini umat Hindu melakukan Nyekeb (Proses membuat buah-buahan yang belum dimasak menjadi masak) pisang atau tape untuk persiapan hari Galungan. Pada hari penyekaban ini merupakan awal Wuku Dungulan yang memiliki maksan patut waspada, buah-buahan memiliki makna sebagai simbol pengekangan diriagar tidak tergoda dengan Bhuta Galungan, karena pada Bhuta Kala
(Sang Hyang Tiga Wisesa) akan turun dan menggoda keyakinan umat Hindu dalam wujud Bhuta Galungan. Oleh karena itu, manusia harus selalu waspada dalam mengendalikan dirinya, mengguatkan batin agar tidak tergoda dengan kekuatan negatif dari Sang Bhuta Galungan.

\section{Kelima, Hari Penyajahan}

Galungan. Hari Penyajahan Galungan dilaksanakan hari senin atau 2 hari sebelum hari raya Galungan. Hari ini digunakan sebagai hari persiapan membuat jajanan (kue) untuk hari raya Galungan. Kata jajan memiliki makna sebagai simbolis adalah mengandung maksud sungguh-sungguh unutk melaksanakan hari raya Galungan. Pada hari penyajahan Galungan ini juga mulai turun Sang Bhuta Kala atau yang biasa disebut dengan Sang Bhuta Dungulan. Oleh karena itu Sang Bhuta Kala bertambah satulagi dan godaannya semakin kuat dan keras, oleh karena itu umat Hindu harus lebih waspada dengan gangguangangguan negatid dan Bhuta Galungan tersebut. Pada hari Penyajahan Galungan ini umat Hindu mulai mempersiapkan diri untuk membuat sesajen/banten dengan harapan melakukan kegiatan ini dapat 
meningkatkan daya konsentrasi diri ke arah yang bersifat suci guna dalam mengalahkan sang Bhuta Galungan agar tidak menggoda umat Hindu.

Keenam, Hari Penampahan

Galungan. Hari Penampahan Galungan dilaksanakan pada hari Selasa Wage Wuku Dungulan atau sehari sebelum hari raya Galungan. Pada hari dilaksanakan penyembelihan binatang ternak seperti, babi, ayam, itik, atau binatang lain yang digunakan untuk keperluan Yadya dan keperluan pest untuk menyambut hari raya Galungan. Pada hari Penampahan Galungan ini turun lagi Sang Bhuta Kala Amangkurat untuk menggoda umat Hindu agar gagal melakukan hari raya Galungan. Untuk terhindar dari golongan umat Hindu harus menghindarkan diri dari pertengkaran. Pada hari raya penampahan Galungan ini yang bertugas menyiapkan sesajen dan persiapan untuk hari raya Galungan ini yang bertugas menyiapkan sesajen dan persiapan untuk hari raya Galungan besok adalah ibu-ibu dan remaja putri, sedangkan pada sore harinya setelah memasak akan diselenggarakan upacara Mabiyaka oleh anggota keluarga yang sudah dewasa, dan dengan setelah itu dilakukan dengan pemasangan Penjor. Kita harus dengan sungguh-sungguh sesuai dengan Dharma atau kebenaran dalam menghadapi hari Penampahan Galungan. Penampahan berasal dari kata "Tampah" yang memiliki arti Junjung. Maksudnya adalah kalau Dharma sudah dijunjung maka Adharma akan kalah. Hal ini disimbolkan dengan nampah babi dan ternak lainnya.

\section{Ketujuh, Hari Raya Galungan.} Hari Raya Galungan dilaksanakan setiap 210 hari atau 6 bulan sekali setiap Budha (rabu) Kliwon Wuku Dungulan, yang merupakan puncak upacara peringatan terhadap dari kemenangan Dharma melawan Adharma sebagai hari Pewadalan Jagat dengan mempersembahkan upacara sesajen pada setiap tempat-tempat suci yang ada dan dilanjutkan dengan melakukan sembayang. Persembahanpersembahan pada hari raya Galungan yang paling utama ditunjukkan kepada manifestasi Sang Hyang Widhi Wasa. Dengan kemenangan Dharma memiliki makna berarti telah terlaksananya kewajiban dan pekerjanaan-pekerjaan yang baik, yang sangat bermanfaat untuk dirinya sendiri, keluarganya, dan untuk semua 
umat manusia. Bagi umat Hindu itu sendiri pekerjaan-pekerjaan yang baik merupakan Yajna, oleh karena itu dalam perayaan dari raya Galungan maka persembahan

Kedelapan, Hari Umanis

Galungan. Hari Umanis Galungan ini dilaksanakan setiap Wraspati Umanis Wuku Dangulan. Pada hari Umanis Galungan ini semua umat Hindu melakukan pensucian dirinya secara lahir dan batin. Setelah mensucikan diri dilanjutkan dengan melakukan haturan sesajen kepada Hyang Widhi Wasa dan segala manisfestasinya, dengan tujuan dengan memohon keselamatan Bhuwana Agung dan Bhuwana Alit. Setelah selesai melakukan sembahyang umat Hindu melanjutkan dengan berkunjung kerumah sanak saudara.

\section{Makna dan Tujuan Galungan}

Hari raya galungan digunakan untuk menyatakan terimakasih dan rasa bahagia atas kemakmuran Sang Hyang Widhi yang dibayangkan telah sudi turun diiringi oleh para Dewa dan Pitara ke dunia. Sehari sebelum Galungan Yaitu pada hari Anggara Wage Dungulan dinamai hari Penampahan, mulai saat mana segala nafsu harus dihilangkan dari badan sebelum menyambut hari suci besoknya. Manusia dilahirkan dalam keadaan awidya (kegelapan), yaitu sifat murka, iri hati, congkak, angkara. Semua sifat ini disimbolkan sebagai Sang Kala Tiga atau Kejahatan yang tiga, diberi gelar sang Bhuta Galungan, Bhuta Dunggulan, Bhuta Amangkurat. Kesadaran umat akan kekuatan suci dibangunkan dengan "abhayakala" yaitu upacara penyucian diri dari kegelapan atau Kala Tiga itu. Bagi para sujana pada malam hari Galungan dilakukan yoga Samadhi, mohon karunia Sang Hyang Widhi. Pada esok harinya sesudah Galungan pada Kamis Umanis Dungulan, umat bersamasama menikmati sisa sajian (Yajna sesa) yaitu karunia guru sejati (Sang Hyang Widhi) dengan melakukan pensucian dan penyembahyangan dirumah masing-masing pada waktu fajar baru menyingsing dengan air wangi (kumkuman) dan air suci (tirtha). Setelah selesai lalu umat hindu berkunjung bersama-sama kunjung mengunjungi, beramah tamah, saling mendoakan keselamatan (Sudharta dan Amaja, 2010:40).

Yang istimewa pada hari raya Galungan ini ialah dipancangkannya "penjor" (bambu berhias) disetiap 
muka rumah sebagai tanda terima kasih atas kemakmuran yang dilimpahkan Tuhan. Bambu tinggi melengkung adalah gambaran dari gunung tertinggi sebagai tempat yang suci. Hiasan yang terdiri dari kelapa pisang; tebu, padi, jajan dan kain adalah merupakan waki-wakil dari seluruh tumbuh-tumbuhan dan benda sandang pangan yang dikaruniai Hyang Widhi Wasa, Tuhan Yang Maha Pengasih dan Penyayang kepada kita manusia (Sudharta dan Amaja, 2010:40).

Hari raya galungan ini juga dapat membuat kesadaran terhadap umat Hindu untuk membedakan kegiatan mana yang dilakukan oleh Dharma (kebaikan) atau Adharma (Keburukan).

\section{Penutup}

Hari raya Idul Fitri dalam Islam dan hari raya Galungan dalam Hindu memiliki persamaan dan perbedaan. Berdasarkan pemaparan diatas maka dapat dilakukan Analisis perbandingan sebagai berikut :

Pertama, Persamaan. Terdapat banyak persamaan di hari raya keagamaan yang memiliki makna sama namun di agama yang berbeda, yaitu contohnya hari raya Idul Fitri dalam Islam dan hari raya Galungan dalam Hindu.
1. Kedua hari raya ini memiliki makna yang sama, Idul Fitri adalah hari raya kemenangan umat Islam karena telah melakukan ibadah selama bulan suci Ramadhan, kegiatan yang dilakukan selama bulan Ramadhan adalah berpuasa dari terbit fajar hingga terbenamnya matahari. Idul Fitri disebut sebagai hari kemenangan umat islam karena dasar kata Idul Fitri itu sendiri adalah kembali kefitrah, dan dapat dilihat dari kata "minal aidin wal faizin" yang artinya semoga kita adalah orang-orang yang kembali kepada kemenangan. Makna kemenangan di hari raya Idul Fitri juga memiliki makna sama di hari raya Galungan, di agama Hindu memiliki hari raya Galungan yang bermakna kemenangan Dharma (kebaikan) melawan Adharma (keburukan). Galungan berasal dari bahasa Jawa Kuno yang memiliki arti kemenangan.

2. Di hari raya Idul Fitri juga melaksanakan halal bihalal yang bertujuan untuk menjalin silaturahmi dan saling memaafkan terhadap sesama. Di dalam agama Hindu Galungan juga melaksanakan kegiatan berkunjung untuk menjalin persaudaraan dan saling memaafkan. Galungan juga memiliki makna rasa 
syukur umat Hindu karena telah diberikan kemakmuran oleh Hyang Widhi. Galungan dilakukan setiap enam bulan sekali (210 hari) sesuai dengan perhitungan kelender Hindu Bali atau dua tahun sekali.

Kedua, Perbedaan. Di kedua hari raya tersebut juga memiliki banyak perbedaan :

1. Idul Fitri dalam Islam jatuh pada tanggal 1 Syawal yang sudah pasti waktunya. Di Indonesia Idul Fitri dilakukan 1 kali dalam 1 tahun. Kegiatan yang dilakukan sebelum hari raya Idul Fitri tersebut hanyalah berpuasa, tidak ada perayaan lain untuk menyambut Idul Fitri.

2. Di dalam Hindu Galungan dilaksanakan setiap 6 bulan sekali, yang artinya 2 kali dalam 1 tahun. Sebelum hari raya Galungan dimulai umat Hindu juga memiliki rangkaian khusus untuk menyambut hari raya Galungan, yaitu Tumpek Wariga, Sugihah Jawa, Sugihan Bali, hari penyekeban, hari penyajahan Galungan, hari penampahan Galungan, Hari raya Galungan, hari umanis galungan

\section{Kesimpulan}

Berdasarkan dengan uraian tentang hari raya Idul Fitri dalam Islam dan hari raya Galungan dalam Hindu (Analisis Perbandingan), maka dapat peneliti simpulkan bahwa hari raya Idul Fitri merupakan sebuah kegiatan keagamaan yang memiliki arti kemenangan umat Islam karena telah melawan hawa nafsu selama 1 bulan penuh dibulan suci Ramadhan. Hari raya Idul Fitri memiliki tahapan pelaksanaan ibadahnya itu shalat I'ed, dimana dihari raya itu juga mewajibkan umat Islam untuk saling bermaaf-maafan, dan menjalin silaturahmi. Di dalam agama Hindu ada juga hari raya Galungan yang memiliki arti kemenangan atas perlawanan Dharma (kebaikan) melawan Adharma (keburukan). Yang upacara galungan juga miliki 2 tahapan, yaitu tahapan persiapan, dan tahapan pelaksaannya. Hari raya galungan juga memiliki arti yang sama agar umat Hindu saling bermaafan dan menjalin silaturahmi terhadap sesama, serta bersyukur kepada Sang Hyang Widhi karena telah memberikan kehidupan ini 


\section{DAFTAR KEPUSTAKAAN}

Abdurrahman Al-Jaziri, Fiqh Madzabib alArba'ah-Dalilun Masyru'iyatun Sholat al-Tdain (Kairo:Daar Al-Hadist, Tt).

Cyril Glase, Ensiklopedia Islam (Jakarta : PT. Raja Grafindo Persada, 1999).

Fathul Baari Ibnu Hajar, Hadist Bukhari, (Jakarta : Pustaka Azzam).

Hannan Hoesin Bahannan Dkk, Tuntunan Ibadah Ramadhan dan Hari Raya (Maktabah Salafy Press, 2002).

I Made Sujana dan I Nyoman Susila, Manggala Upacara, (Denpasar: Widya Dharma, 2012).

Ibrahim Anis, Al-Mu'jam al-Wasieth, (Mathabi' Darul Ma'arif, 1392 H1972 M), juz II.

Ihyaul Ulumuddin, Makna Perayaan Hari Raya Idul Fitri dan Hari Natal (Analisa Perbandingan), (Skripsi S1, UIN Syarif Hidayatullah Jakarta, 2010).

Jejen Musfah, Nilai Edukasi Idul Fitri, Go Cakrawala, 2016.

Journal Agung Prabowo, "Tiga Cara Menentukan Nama Wuku Dalam Pawnkon Saka", Volume 7 Nomor 1, Juni 2015.

Journal Dewa Nyoman Sucita, "Upacara Mejeripen Pada Hari Raya Gulungan di desa Desa Pendawa Kabupaten Banduleng".

Journal Wayan Musna, "Upacara dan Makna Filosofis Hari Raya Sugian Jawa dan Sugian Bali”.
Ketut Wiana, Makna Hari Raya Hindu, (Paramita, Surabaya, 2009).

Khotimah, Agama Hindu dan AjaranAjarannya, (Pekanbaru, Daulat Riau), 2013.

Krisnawati, Makna Hari Raya Galungan Bagi Masyarakat Hindu(Studi Di Pura Agung Jagatnatha Pekanbaru). (Skripsi S1, UIN SUSKA Riau 2019).

Michael Keene, Agama-Agama Dunia, (Yogyakarta : Kanisius, 2006).

Muhammad Nashiruddin al-Bani, Shaheh Sunan Abu Daud, (Jakarta: Pustaka Azzam, 2007).

Shalahuddin Hamid, Hari-Hari Besar Islam, Jakarta: Intimedia Cipta Nusantara, 2003).

Syekh Usman bin Hasan, Durratun Nashibin , (Surabaya: Pustaka Nuun).

T.M. Hasbi Ash Shiddiqie, Problematika Idul Fitri, (Yogyakarta: Menara Kudus, 1972).

Tjok Rai Sudharta dan Ida Bagus Oka Punia Atmaja, Upadesa Tentang Ajaran-Ajaran Agama Hindu, Surabaya : Paramita, 2010).

Wahbah az-Zuhaili, Fiqib Islam Jilid 2, (Jakarta: Gema Insani, 2010).

Yudha Triguna Dkk, Swatika Rana Pedoman Ajaran Hindu Dharma, (Jakarta, PT. Mabhati, 2014).Soerjono Soekanto. Sosiologi Suatu Pengantar. Jakarta: PT. Raja Grafindo Persada. 1982.

Sosiologi Suatu Pengantar. Jakarta: Rajawali Pers. 2012. 
Soerjono Soekanto dan Budi Sulistyowati. Sosiologi Suatu Pengantar. Jakarta: PT RajaGrafindo Persada. 2013.

Sri Dhammananda. Keyakinan Umat Buddha. Jakarta Barat: Yayasan Penerbit Karaniya. 2005.

Sudirman Tebba. Islam Pasca Orde Baru. Yogyakarta: Tiara Wacana Yogya. 2001.

Sugiyono. Metode Penelitian Kuantitatif, Kualitatif dan R\&D. Bandung: Alfabeta. 2009.

Sulistyo Basuki. Metode Penelitian. Jakarta: Wedatama Widya Sastra. 2006.

Suryan A. Jamrah. "Toleransi Antarumat Beragama: Perspektif Islam." Jurnal Ushuluddin 23. No. 2. JuliDesember 2015.

Syahrin Harahap. Teologi Kerukunan. Jakarta: Karisma Putra Utama. 2011.

Syed Mahmududdunnasir. Islam (Konsepsi dan Sejarahnya). Bandung: PT Rosdakarya. 2011.

Tarpin. Laporan Penelitian Kualitas Interaksi antara Penduduk Berbeda Agama di Komplek Guru Labuh Baru Pekanbaru. Balitbang Fakultas Ushuluddin: UIN Suska Riau.2009.

Tim Penyusun Pusat Bahasa Departemen Pendidikan Nasional. Kamus Bahasa Indonesia. Jakarta: Pusat Bahasa. 2008.

Tim Prima Pena. Kamus Ilmiah Populer. Jakarta: Gitamedia Press. 2006.

W.A. Gerungan. Psikologi Sosial. Badung: PT. Refika Aditama. 1988.
Psikologi Sosial. Bandung:

PT Refika Aditama. 2002. 